\title{
Electric Energy Consumption Monitoring System and Restricting Temperature Settings Air Conditioning Equipment
}

\author{
Ali A. S. Ramschie \\ Department of Computer \\ Engineering \\ Manado State Polytechnic
}

\author{
Johan F. Makal \\ Department of Electrical \\ Engineering \\ Manado State Polytechnic
}

\author{
Veny V. Ponggawa \\ Department of Computer \\ Engineering \\ Manado State Polytechnic
}

\begin{abstract}
In operating air conditioning equipment, often the user selects the temperature setting at the lowest temperature setting, for example at a temperature setting of $16^{\circ} \mathrm{C}$ to $18^{\circ} \mathrm{C}$. This can result in a waste of electrical energy, where the lower the temperature setting chosen, the longer the compressor works to reach room temperature according to the temperature setting chosen. Another thing that can cause the waste of electrical energy from the operation of air conditioning equipment is in the case of the user's ignorance of the amount of consumption of electrical energy consumed by the air conditioning equipment.
\end{abstract}

This study aims to create a system that can operate in 2 operating modes, namely energy saving operation mode by limiting the temperature regulation of air conditioning equipment to a range of $24^{\circ} \mathrm{C}$ to $27^{\circ} \mathrm{C}$ and normal operating modes, and can monitor electrical energy consumption and the price paid in rupiah from the operation of the equipment.

From the results of the tests carried out, it was found that the system that was made could limit the temperature regulation of the air conditioning equipment in operation settings $24^{\circ} \mathrm{C}$ to $27^{\circ} \mathrm{C}$ in energy saving operation mode, so as to minimize the occurrence of waste of electrical energy from the air conditioning equipment.

\section{Keywords}

Monitoring, Electrical Energy, Energy Saving, Air Conditioning.

\section{INTRODUCTION}

One of the causes of electrical energy waste from the use of air conditioning equipment is in terms of temperature regulation. The lower the temperature setting selected, the greater the consumption of electrical energy supplied by the air conditioning equipment, because the operating time of the compressor takes longer to reach room temperature in accordance with the selected temperature setting. In addition, the thing that can influence the occurrence of electrical energy waste from the operation of air conditioning equipment is in terms of electrical energy intake from the equipment, where the user does not know how much electrical energy consumption of the air conditioning equipment when operating, so the user can adjust the temperature air conditioning equipment operation at a higher setting to avoid electricity waste [1][2][3][4].

One of the efforts of the Indonesian government in terms of saving electricity for the operation of air conditioning equipment, is the issuance of Regulation of the Minister of Energy and Mineral Resources of the Republic of Indonesia No. 13 of 2012 concerning saving electricity consumption as stated in Article 4 Paragraph 2a number 6 which states that when using air conditioning equipment, it is done by regulating temperature and relative humidity in accordance with Indonesian National Standards, namely for workspace temperatures ranging from $24^{\circ} \mathrm{C}$ to $27^{\circ} \mathrm{C}$ with humidity air between $55 \%$ to $65 \%$, and for lobbies and corridors temperatures range from $27 \mathrm{oC}$ to $30 \mathrm{oC}$ with air humidity between $50 \%$ to $70 \%$ [5].

For this reason, this research aims to create a system that can limit the temperature regulation of air conditioning equipment in the range of $24^{\circ} \mathrm{C}$ to $27^{\circ} \mathrm{C}$ for energy saving and normal operation settings, and can monitor electricity consumption and the price paid in rupiah from the operation of air conditioning equipment.

In producing a system of limiting temperature regulation and monitoring the electrical energy consumption of air conditioning equipment, it is necessary to support modules that are integrated with each other, where the modules include: Arduino Uno microcontroller based on the ATMega 328 microcontroller, which functions as a controller of the entire system work, in terms of temperature regulation and detection and information on the consumption of electrical energy from air conditioning equipment [6]; current sensor ACS 712 which functions as a sensor to detect the amount of electric current consumption from air conditioning equipment [7] [8], where the detection data will later be processed by the controller, then informed as electrical energy consumption data in watt hours (Wh) and payment data for electricity consumption in rupiah (Rp); infrared sensor (IR sensor), which functions as a medium for sending data to the temperature regulation of the air conditioning equipment; Liquid Cristal Display (LCD), which is used as an information media, to inform the process of regulating the temperature of air conditioning equipment, including information on the amount of electrical energy consumption and the price to be paid for the electrical energy consumption of the air conditioning equipment [9].

To run a system of limiting temperature regulation and monitoring the electrical energy consumption of air conditioning equipment, a program is needed that is implanted into the Arduino Uno microcontroller, where the software used for making the program is the Arduino IDE, with reference to the flowchart created [10] [ 11]. 
As for studies related to this paper, as has been done by:

1. Chiou,et al (2008), published in the journal Energy and Buildings entitled "The study of energy-saving strategy for direct expansion air conditioning system", in which research is related to energy-saving procedures in DX Air Conditioning system, with periodic downtime method, by setting the system's operating period and the system shutdown period of two ACs [12].

2. Zhou, et al (2007), published in the journal Energy and Buildings entitled "Energy simulation in the variable refrigerant flow air-conditioning system under cooling conditions", this research compare the energy consumption from air conditioning system with 3 different methods, namelyVariableRefrigerantFlow (VRF) system, Variable Air Volume (VAV) system and fan-coil plus fresh air (FPFA) system. The study was conducted with a simulation using the Energy Plus software. Simulation results show that the energy-saving potential of the VRF system reaches $22.2 \%$ and $11.7 \%$, compared to VAV and FPFA systems [13].

3. Widell, et al. (2009) published in the International Journal of Refrigeration under the title "Reducing power consumption in multi-compressor refrigeration system", using linear programming model to minimize the compressor's electric energy consumption, the compressor's operation will be optimized according to the required load [14].

4. Ali Ramschie, at al. (2016), published in the International Journal of Computer Applications entitled Algorithms Air Conditioning Air Filter Detection System for Electric Energy Savings, the research conducted is related to making a control system algorithm that can detect when air filters from AC equipment have been dirty. When the $\mathrm{AC}$ air filter is dirty, the system will deactivate the air conditioner and inform it through the sound of the alarm and through the LCD display that the $\mathrm{AC}$ needs to be treated in connection with the air filter is dirty, so that waste of electrical energy can be avoided [15].

\section{METHODOLOGI}

The method used in the process of producing a system of limiting temperature regulation and monitoring of electrical energy consumption of air conditioning equipment is the prototyping method, where the stages include: the design stages which consist of designing system block diagrams and designing software for system operation purposes in the form of flow diagram. The next stage is the manufacturing process which consists of making the system with reference to the block diagram that has been made which is simulated through a Proteus simulation program and making software that refers to the flow diagram that has been produced. Next is the system testing phase which is carried out through a Proteus simulation program.

\subsection{System Design}

The control application developed in this paper is a system of limiting temperature and monitoring the consumption of electrical energy from air conditioning equipment, where the working principle of the system is as follows: When the system is first activated, the system will run normal operating mode, where in this normal operating mode the user can adjust the temperature of the air conditioning equipment from $16^{\circ} \mathrm{C}$ to $28^{\circ} \mathrm{C}$. The temperature setting selection is made by pressing the temperature rise button for the temperature setting up and the temperature button down for the temperature setting. To switch from normal operating mode to energy saving operation mode, what needs to be done is to press the energy saving button. When the energy saving button is pressed, the temperature setting is automatically limited from $24^{\circ} \mathrm{C}$ to $27^{\circ} \mathrm{C}$. When the temperature setting is at $24^{\circ} \mathrm{C}$, the temperature down button cannot be used, so the temperature setting cannot drop below the $24^{\circ} \mathrm{C}$ limit. The temperature down button will function, if the temperature setting selected above $24 \mathrm{oC}$. When the system is in energy saving mode, users can switch to normal mode by pressing the normal mode button. The LCD display functions to inform the operation of the air conditioner equipment whether it is in normal operating mode or in energy saving operation mode. Besides that, the information displayed is in the form of the amount of electricity consumption and the price paid for the air conditioning equipment as a process of monitoring the consumption of electricity. as well as information about the selected temperature setting. The system block diagram is shown in Figure 1.

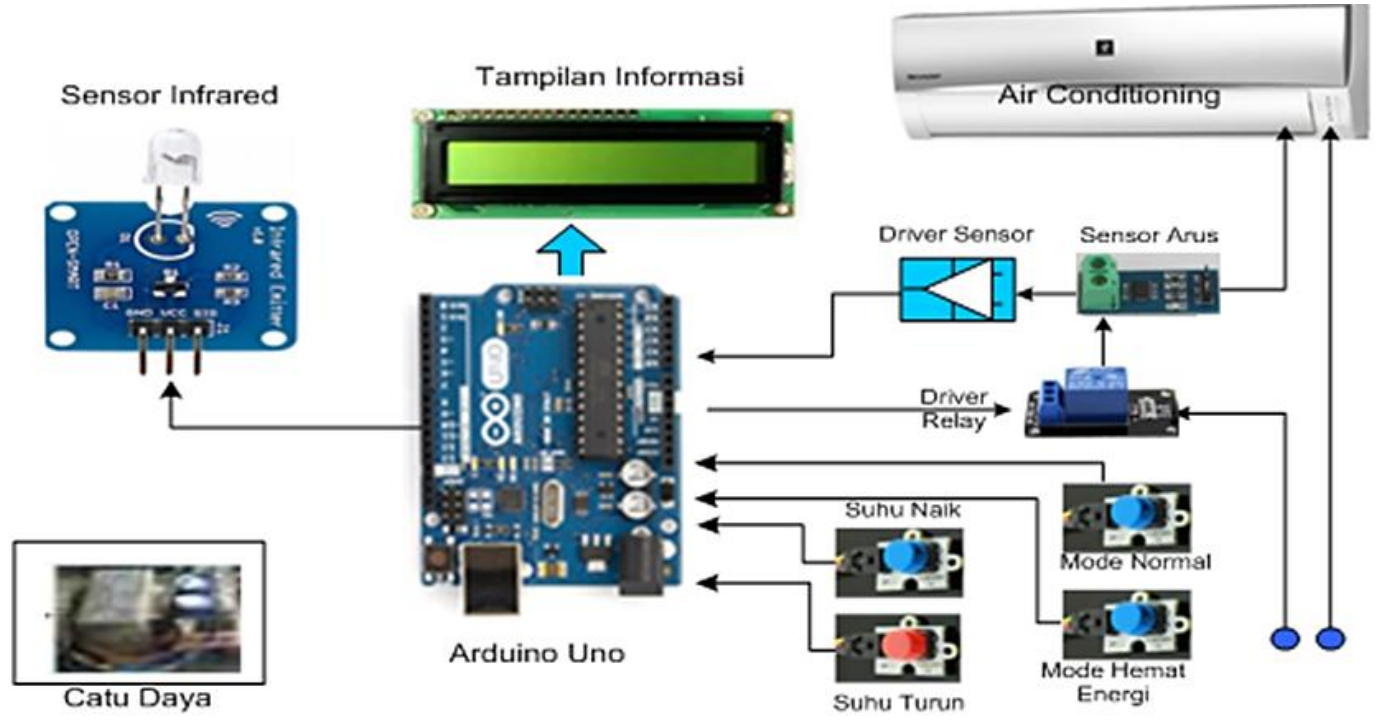

Fig 1: Block diagram system 
The description of the Block diagram in Figure 1, is described as follows:

1. Arduino Uno, a microcontroller device that functions as a central working controller of the whole system.

2. Information display, in the form of an LCD that functions to inform about the temperature regulation, the amount of electricity consumption and the price paid for operating the air conditioning equipment.

3. Infrared sensor, functions as a medium for temperature regulation of air conditioning equipment, the operation of which is regulated through Arduino Uno.

4. ACS712 Current Sensor, serves as a detector for the current consumption of air conditioning equipment.

5. Driver Relay, functions as a magnetic switch that is operated through Arduino Uno, to activate and deactivate the work of the air conditioning equipment.

6. On button, functions as input to Arduino Uno, to activate the work of the whole system.

7. The Off button, functions as an input to Arduino Uno, to deactivate the work of the whole system.

8. Normal Mode Button, functions to select the air conditioner equipment settings for normal operation, without limited temperature settings.

9. Energy saving mode button, functions to select energy saving mode where the temperature setting is limited from $24 \mathrm{oC}$ to $27 \mathrm{oC}$.

10. The power supply functions as a voltage supplier to all parts of the system that are integrated with each other.

\subsection{Flow chart System (Algorithm)}

In the software design process, the initial step taken is to make a flow chart that represents the working sequence of the system for operating the control system of temperature limitation and monitoring the electrical energy of air conditioning equipment. The flowchart of the temperature limiting control system and the electrical energy monitoring of air conditioning equipment is shown in Figure 2.

Description algorithm of the system as follows:

1. When the system is first activated, the system will read the energy saving button. If the energy saving button is not pressed, the system will operate in normal mode, where the temperature regulation of the air conditioning equipment can be used as in normal conditions, ie from the $16^{\circ} \mathrm{C}$ setting to $28^{\circ} \mathrm{C}$ settings. This situation will continue until the system detects a power saving mode button press. If the system detects a power saving button press, the system will enter the program section for setting the power saving mode.

2. When the system enters electricity saving mode, the air conditioning temperature setting is automatically set at $24^{\circ} \mathrm{C}$. in addition, the temperature down button for setting the temperature down on the air conditioner is deactivated. Then the system will read the button presses the temperature rises. If the temperature rise button is not pressed, the system will go to the current sensor data reading process, process the data into $\mathrm{kWh}$ data and pay price (Rp.), Then output it as information through the LCD display. If it is detected that the temperature button presses up, the temperature will be set at $25^{\circ} \mathrm{C}$, then the system will activate the temperature down button, so that the temperature selection below $25^{\circ} \mathrm{C}$ can be made $\left(24^{\circ} \mathrm{C}\right)$. The temperature rise button will be deactivated when the temperature setting has been set at $27^{\circ} \mathrm{C}$. When the system is in the power saving mode, the system will continue to read whether the normal mode button is pressed or not. If the normal mode button is pressed, the system will enter the normal mode section.

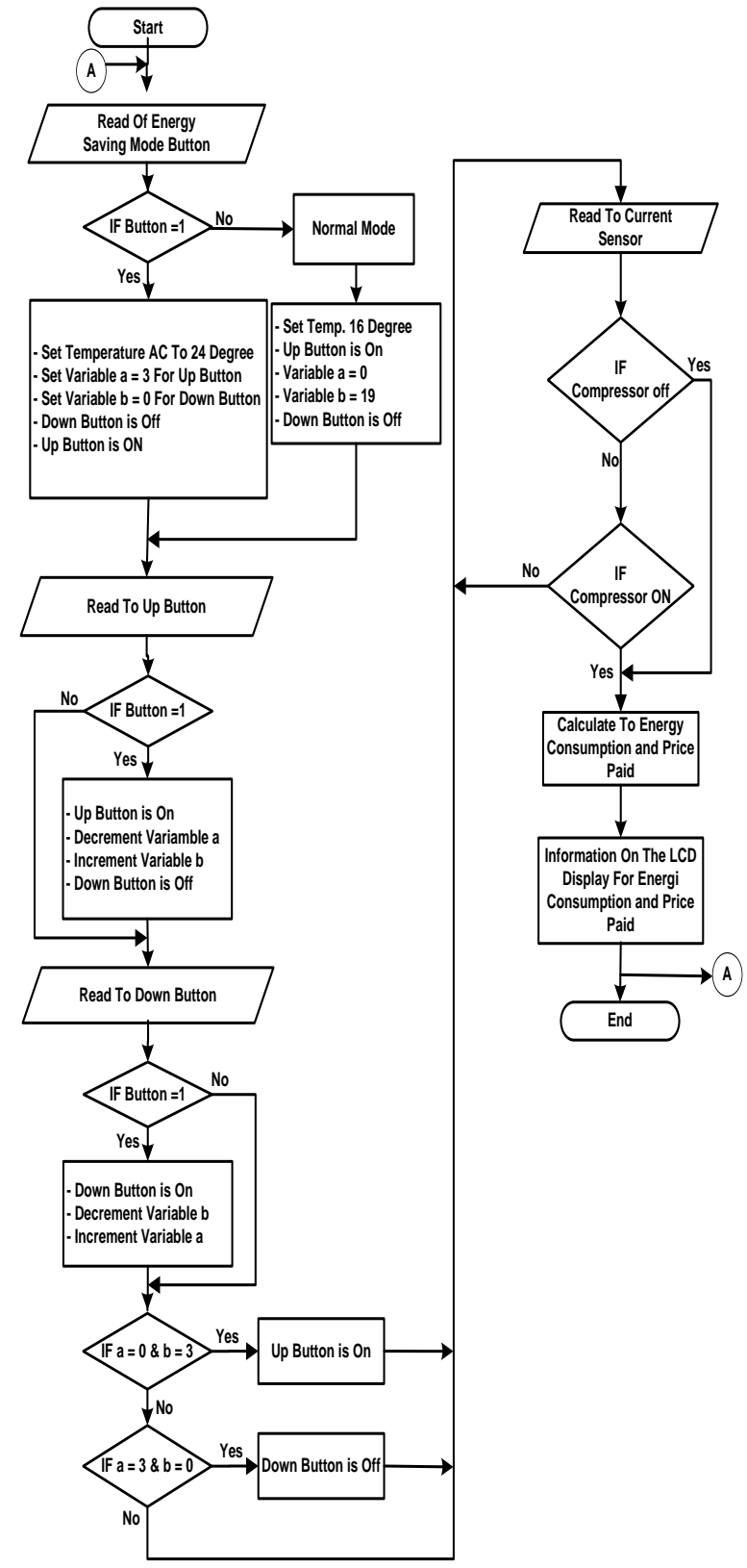

Fig 2:Flowchart system

\subsection{Sistem Simulation Making}

Making a system simulation is done by using the Proteus simulation program, where in this simulation program, an integrated series of systems is made which refers to the design results in the form of block diagrams that have been made. The system simulation is shown in Figure 3. 


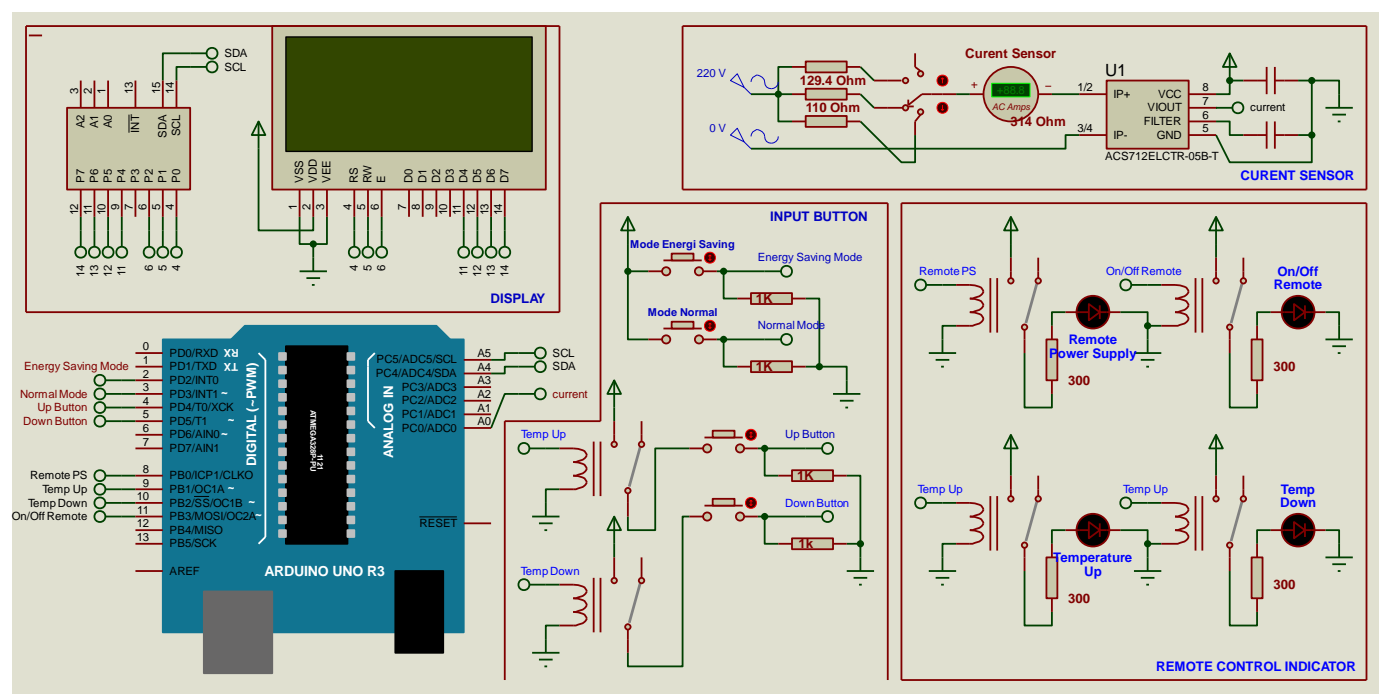

\section{RESULT AND DISCUSSION}

The system simulation testing process aims to obtain data in connection with the work system that is made, whether the system has been made to function in accordance with the results of the design. System simulation testing is done through the Proteus simulation program, based on the simulation design that has been produced in the process of making hardware simulations. To run a simulation of the temperature limiting system for electrical equipment to save electricity, software is needed that is implanted into the Arduino Uno controller, where the embedded program is a program that has been generated through the stages of making software. The testing process includes:

\subsection{System Testing When First Activation}

The first time the system is activated, the system will enter the program section for normal mode settings, where in normal mode, the work of the air conditioning equipment will function normally, where the temperature regulation process can be carried out from the $16^{\circ} \mathrm{C}$ setting up to the highest limit

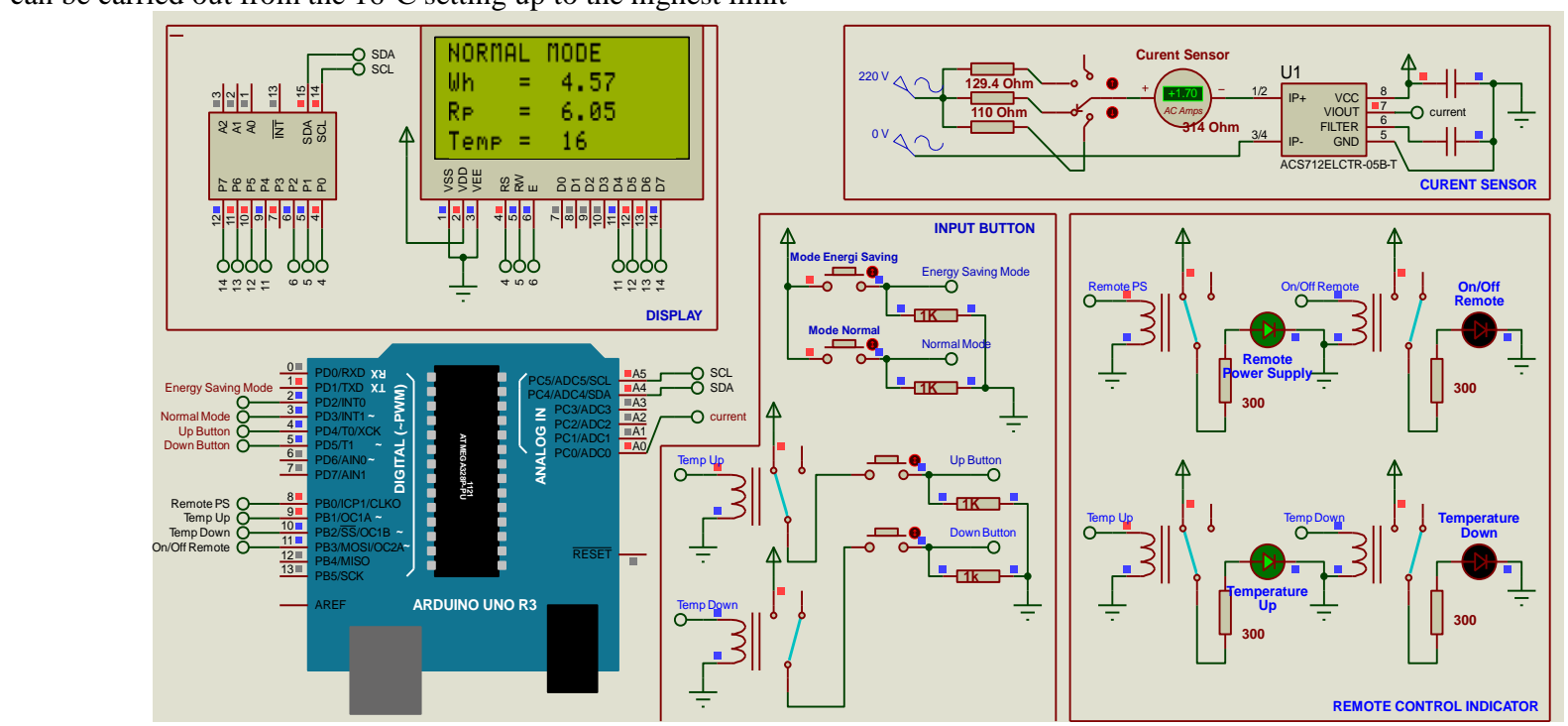

Fig 4: Tests when the system is first activated of the equipment temperature setting air conditioning. Tests when the system is first activated in the normal operating mode state are shown in Figure 4.

From the test results as shown in Figure 4, it appears that when the system is first activated, the system will enter the normal mode of operation. In normal mode operation, the temperature setting of the air conditioning equipment is automatically set at $16^{\circ} \mathrm{C}$. For setting the temperature selection when the system is first activated, the system automatically activates only the function of the temperature rise button through the active relay which functions as an input voltage provider to the temperature rise button, while the temperature drop button cannot be used, because it does not get an input voltage, because The relay is inactive. Besides that, the system will inform the user that the current operating mode is the normal mode, with the initial temperature setting at $16^{\circ} \mathrm{C}$. The process of regulating the temperature selection can be carried out at settings of $16^{\circ} \mathrm{C}$ to $28^{\circ} \mathrm{C}$. 
When choosing a temperature above $16^{\circ} \mathrm{C}$, for example the temperature $17 \mathrm{oC}$, the system will automatically activate the temperature button up and the temperature button down, so that the temperature selection can be made to select a temperature below $17^{\circ} \mathrm{C}$ or above $17^{\circ} \mathrm{C}$. The choice of temperature of $17^{\circ} \mathrm{C}$ is shown in Figure 5.

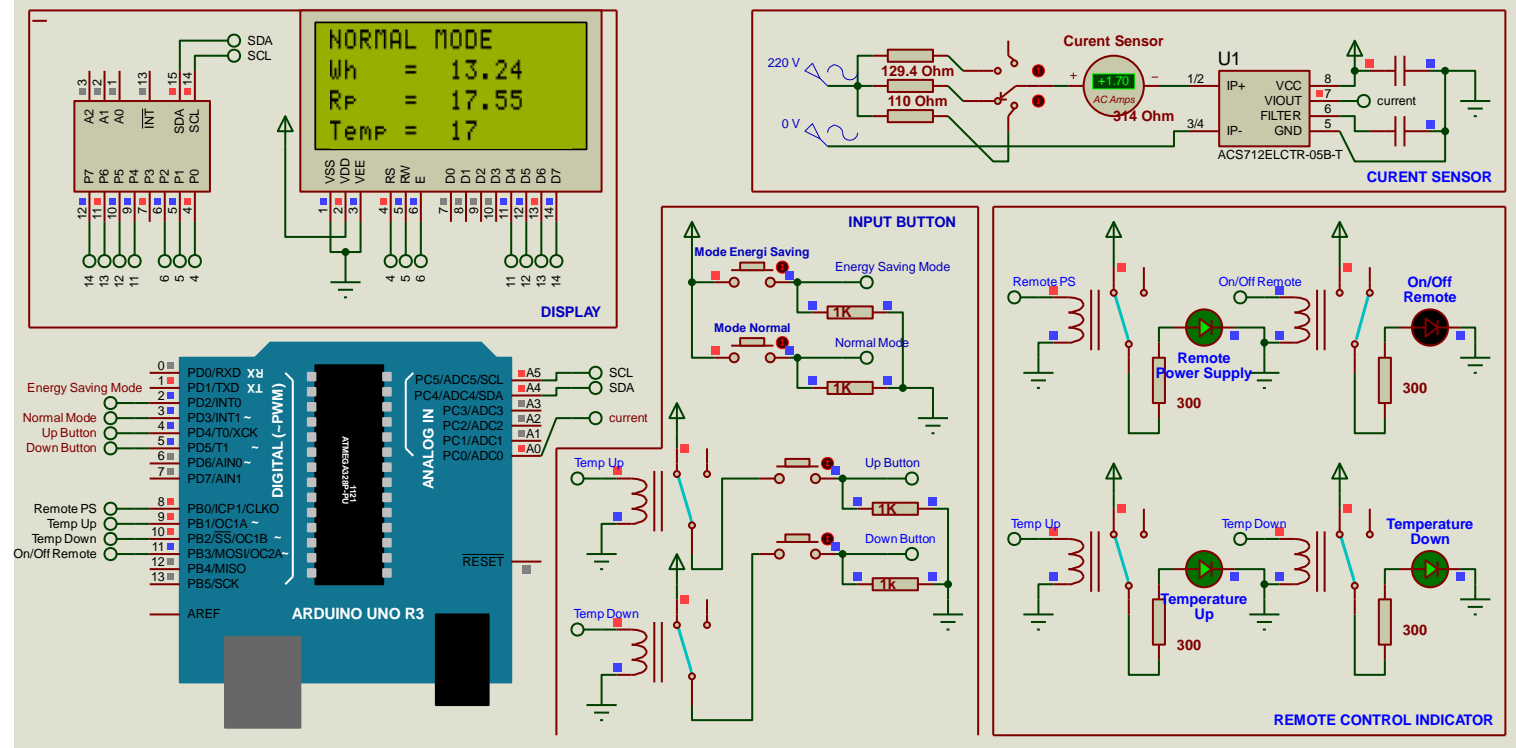

Fig 5: When choosing a temperature above $16^{\circ} \mathrm{C}$

\subsection{System Testing When First Activation}

To switch from normal mode to energy saving mode, to do is press the energy saving mode button. When the system enters energy saving mode, the system automatically adjusts the temperature setting to $24^{\circ} \mathrm{C}$. In the energy saving mode section, the temperature settings that can be performed on air conditioning equipment are limited to the range of $24^{\circ} \mathrm{C}$ to $27^{\circ} \mathrm{C}$ through the activation of the power supply on the temperature rise button and deactivation of the electricity supply at the temperature down button. The energy saving mode system test is shown in Figure 6.

From the results of system simulation testing for energy saving mode, as shown in Figure 6, it appears that only the temperature button up is active, while the down temperature button is inactive. It is intended that temperature settings below $24^{\circ} \mathrm{C}$ cannot be selected, in order to avoid the lowest temperature selection from operating air conditioning equipment, so as to avoid the waste of electrical energy.

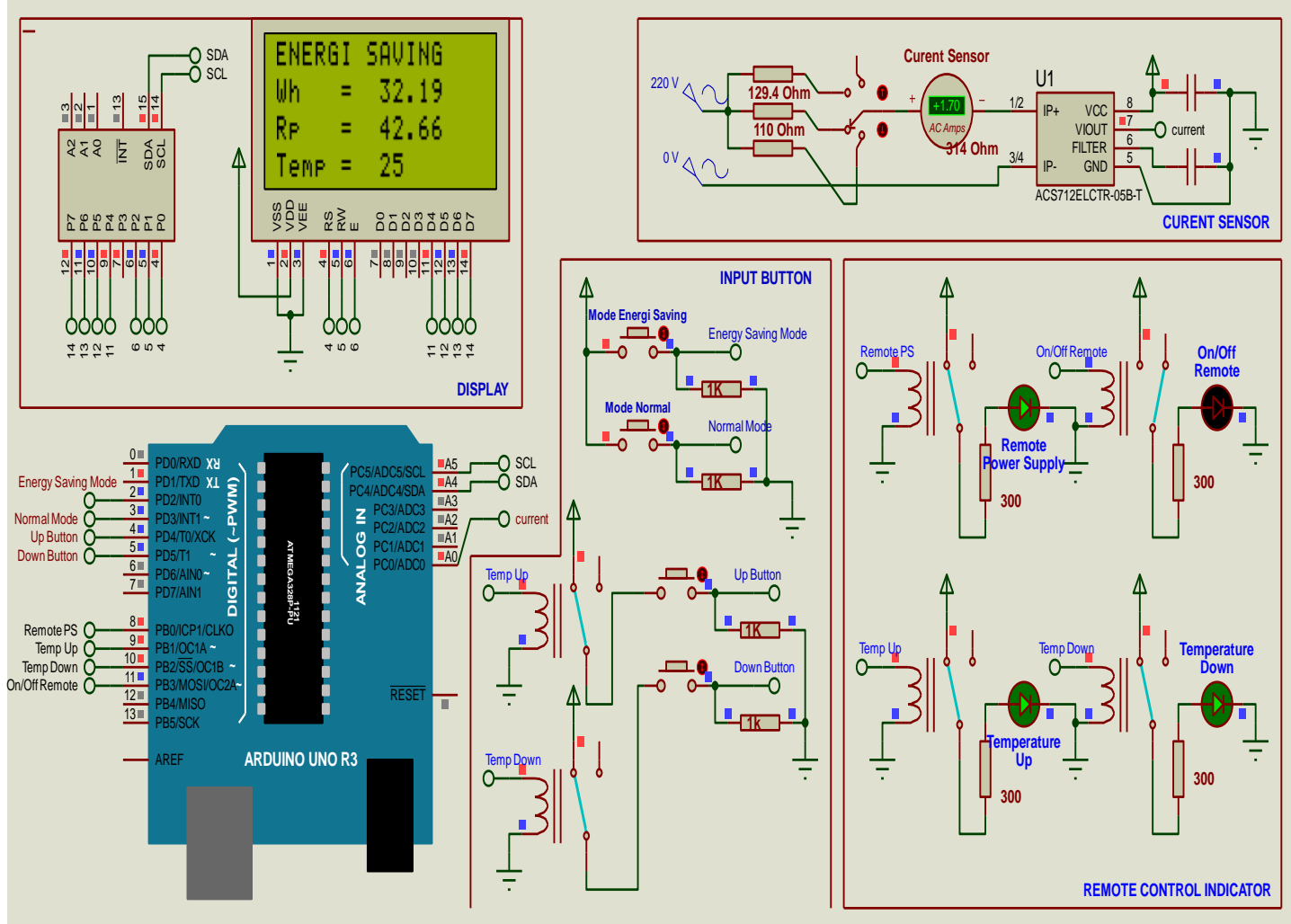

Fig 6: The energy saving mode system test 
The temperature drop button will be activated, if the system detects that the temperature setting of the air conditioning equipment is above $24^{\circ} \mathrm{C}$, as shown in Figure 7. The air conditioning temperature selection process in this energy saving mode can only be carried out in the range of $24^{\circ} \mathrm{C}$ to $27^{\circ} \mathrm{C}$.

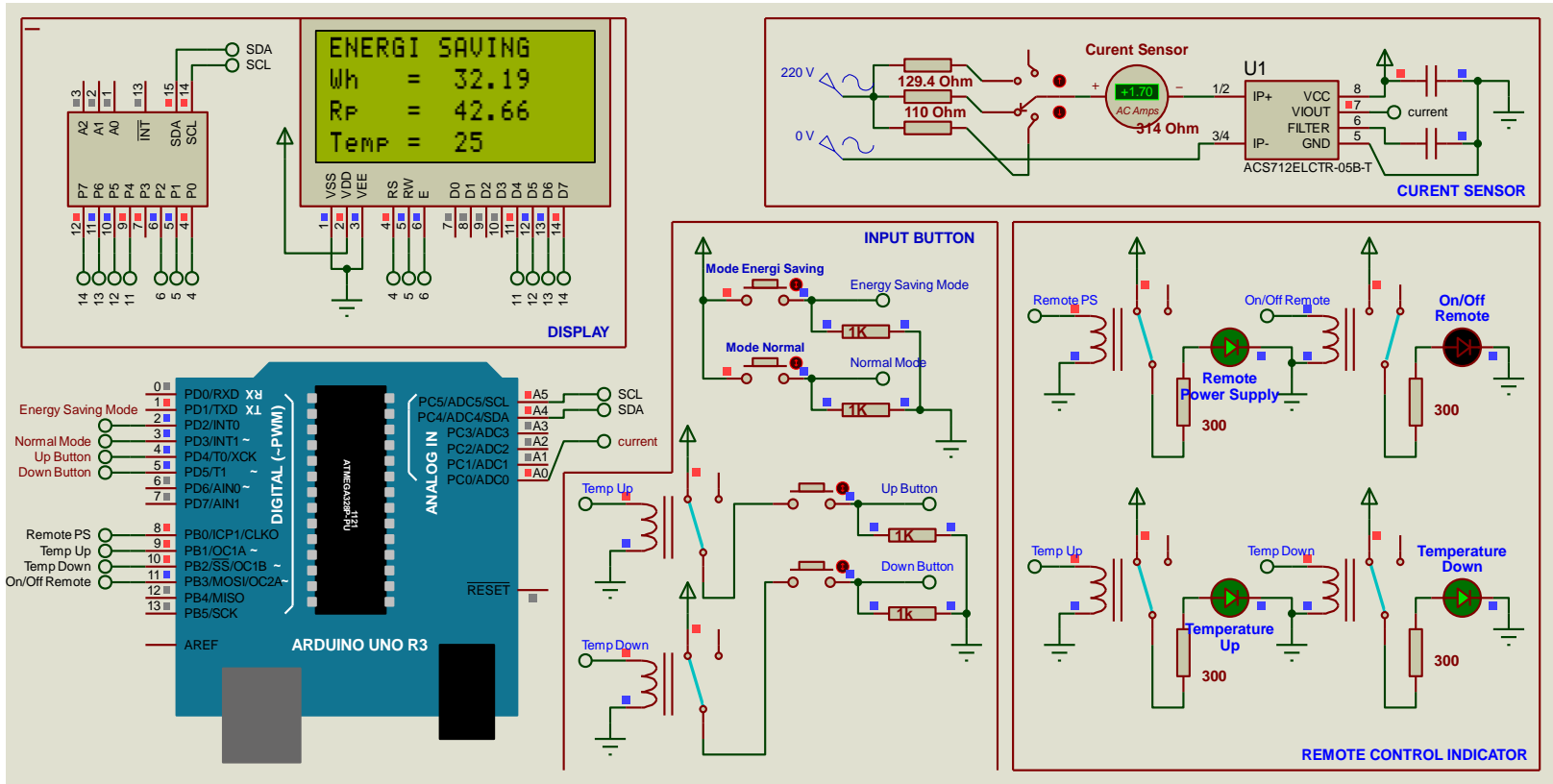

Fig 7: The temperature drop button will be activated

When the selection of the operating temperature of the air conditioning equipment has reached the maximum limit, in this case the setting has reached $27^{\circ} \mathrm{C}$, the system will automatically deactivate the temperature selection process above $27^{\circ} \mathrm{C}$, by deactivating the temperature rise button work, through deactivating the relay work which functions as a power supplier for the increase button temperature. Temperature options above $27^{\circ} \mathrm{C}$ are shown in Figure 8 .

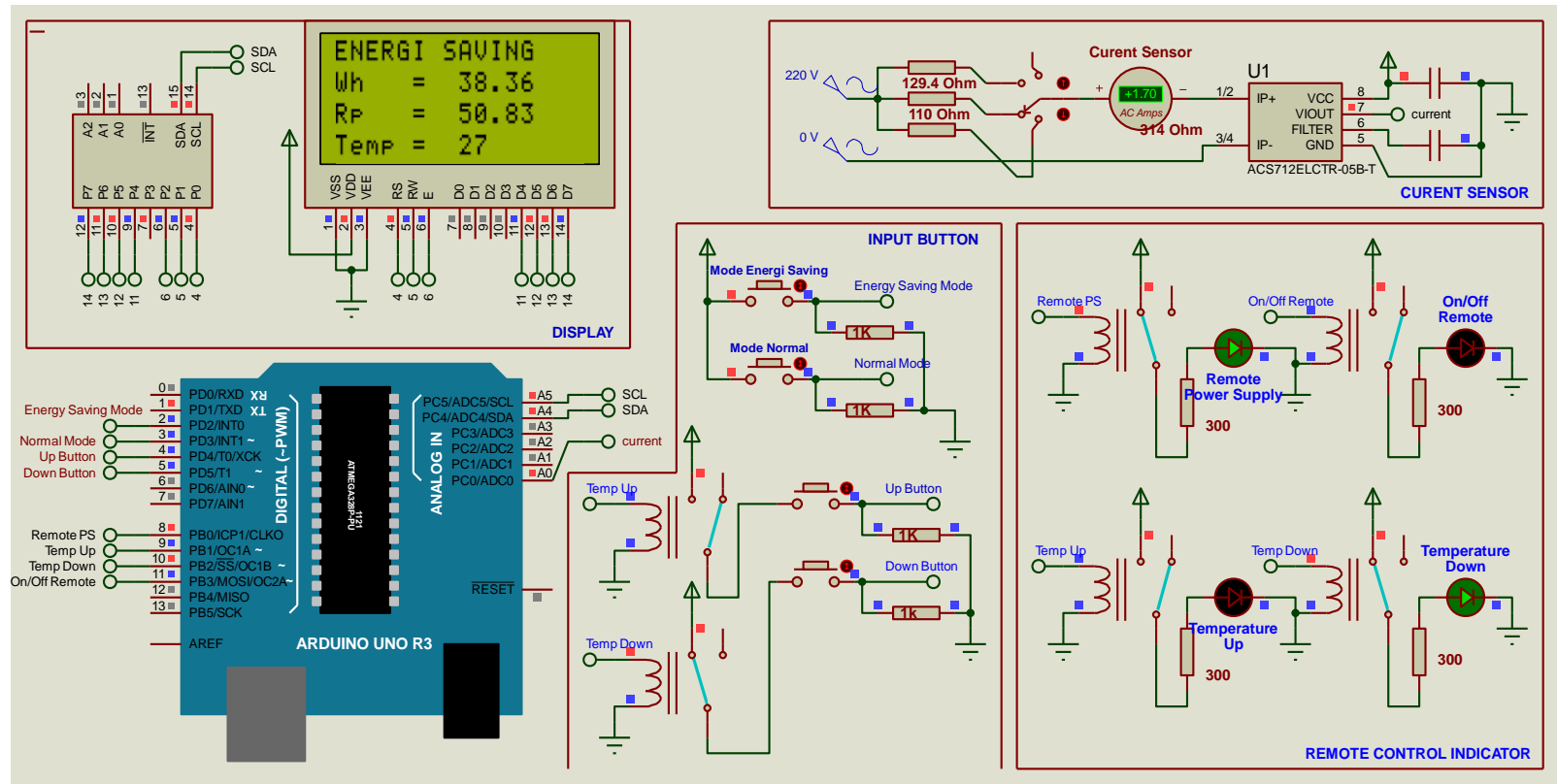

Fig 8: Temperature options above $27^{\circ} \mathrm{C}$

\subsection{System Testing For Monitoring The Process Of Electric Energy Consumption In Air Conditionng Equipment}

To find out the amount of electricity consumption (Wh) and the amount to be paid $(\mathrm{Rp})$ from the operation of air conditioning equipment, the system is tested in terms of the process of monitoring electricity consumption and the price to be paid in Rupiah (Rp). System testing for the monitoring process is shown in Figure 9.

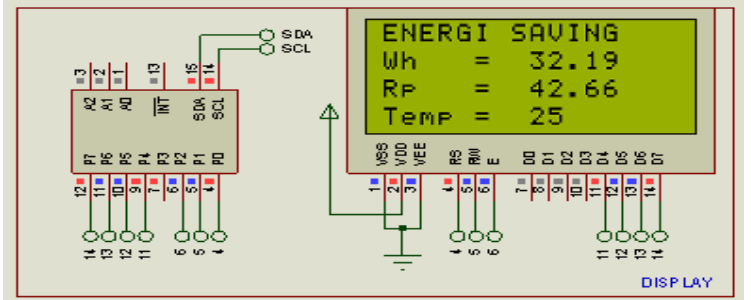

Fig 9: System testing for the monitoring process 
From the results of tests conducted as shown in Figure 9, it appears that the system can carry out a process of monitoring the consumption of electrical energy and the amount of the price paid in Rupiah from the operation of air conditioning equipment and can inform it through the LCD display.

Part of the program carried out for the process of monitoring electricity consumption and the total paid price in Rupiah from the operation of air conditioning equipment is as follows:

The initial stage of the system is to read the value of the electric current consumed by the air conditioning equipment that is entered through the ADC, then the data read by the ADC will be processed to obtain the current value. The program part for the process of reading the value of electric current is as follows:

\section{void read_adc()}

\section{dataADC $=$ analogRead $($ current_sensor $)$;}

voltage_input $=(($ dataADC $* 5.0) / 1024)$;

current $=(($ voltege_input $\mathbf{-}$ 2.5 $) / \mathbf{0 . 1 8 6})$;

delay (300);

calculate_wh_Rp();

After the ADC data reading process is complete, the system will enter the program to calculate the amount of electricity consumption in watt hours (Wh) and the amount to be paid for electricity consumption in Rupiah ( $\mathrm{Rp}$ ) from the operation of the air conditioning equipment, as for the part the program is as follows:

$$
\begin{aligned}
& \text { void calculate_wh_Rp }() \\
& \left\{\begin{array}{l}
\text { p }=(220 * \text { current }) ; / / \text { Electric Power Calculation } \\
\mathbf{i}=\mathbf{i}+\mathbf{p} ; / / \text { Calculate For Total Current } \\
\mathbf{W h}=((\mathbf{1 . 0 / 3 6 0 0}) * \mathbf{i}) ; / / \text { Calculate For Watt Hours } \\
\mathbf{R p}=((\mathbf{W h} / \mathbf{1 0 0 0}) * \mathbf{1 3 2 5}) ; / / \text { Calculate For Paid Price }
\end{array}\right.
\end{aligned}
$$

Next, the process of calculating the amount of electrical energy consumption in watt hours (Wh) and the amount that must be paid for electricity consumption in Rupiah (Rp) from the operation of air conditioning equipment, then the system will inform via the LCD screen, where part of the program being run is as follows:

lcd.setCursor(0, 2);

Icd.print("Rp = ");

lcd.setCursor(8, 2);

String paid price $=$ String $(\mathbf{R p})$;

lcd.print(paid price);

lcd.setCursor (0, 1);

lcd.print("Wh = ");

Icd.setCursor $(8,1)$;

String watt hours = String $($ Wh $)$;

lcd.print(watt hours);

$\operatorname{delay}(300)$;
\}

From the results of monitoring carried out for 1 hour of operation, the system created can save electricity consumption of electricity to the operation of air conditioning equipment, by limiting the temperature regulation, which will only operate in the range of $24^{\circ} \mathrm{C}$ to $27^{\circ} \mathrm{C}$. From the results of tests carried out, for normal mode operation at a temperature setting of $16^{\circ} \mathrm{C}$, the electrical energy consumption is 379.1 $\mathrm{Wh}$, and for energy-saving operating modes at a temperature setting range of $24^{\circ} \mathrm{C}$ to $27 \mathrm{oC}$, it is measured for setting the temperature of $24^{\circ} \mathrm{C}$ electricity consumption of $323.35 \mathrm{Wh}$, for setting the temperature of $25^{\circ} \mathrm{C}$ electricity consumption of $308.48 \mathrm{Wh}$, for setting the temperature of $26^{\circ} \mathrm{C}$ the consumption of electrical energy is $289.90 \mathrm{Wh}$ and for setting the temperature of $27^{\circ} \mathrm{C}$ electricity consumption is 275.03 Wh.

\section{CONCLUSIONS}

From the results of the tests carried out it can be concluded several things, namely:

1. The system that is made can limit the temperature regulation of the air conditioning equipment in operation settings $24 \mathrm{oC}$ to $27 \mathrm{oC}$ in energy saving operation mode, so as to minimize the occurrence of electrical energy waste from the operation of the air conditioning equipment. From the results of tests carried out, for normal mode operation at a temperature setting of $160 \mathrm{C}$, the electrical energy consumption is $379.1 \mathrm{Wh}$, and for energy-saving operating modes at a temperature setting range of $24 \mathrm{oC}$ to $27 \mathrm{oC}$, it is measured for setting the temperature of $24 \mathrm{oC}$ electricity consumption of 323.35 $\mathrm{Wh}$, for setting the temperature of $25 \mathrm{oC}$ electricity consumption of $308.48 \mathrm{Wh}$, for setting the temperature of $26 \mathrm{oC}$ the consumption of electrical energy is $289.90 \mathrm{Wh}$ and for setting the temperature of $27 \mathrm{oC}$ electricity consumption is $275.03 \mathrm{Wh}$.

2. The system created can monitor and inform the amount of electrical energy consumption in Wh and the price paid in Rupiah from the air conditioning equipment through the information displayed on the LCD display, so that savings on the operation of the air conditioning equipment can be achieved.

\section{ACKNOWLEDGMENTS}

Many thanks to the organizers of the International Journal of Computer Application (IJCA) which has provided an opportunity for authors to publish this paper and to the Ministry of Research and Technology who has funded this research so as to produce a scientific work as well as to the Manado State Polytechnic Institute as well Colleagues who have helped so much that the author can complete this writing.

\section{REFERENCES}

[1] Hidayat T, "Analisis Penghematan Listrik pada AC Split dengan Refrigran Hidrokarbon disertai perbaikan faktor daya" Jurnal Teknosain Vol. 8, 2011.

[2] Ilham, Amil Ahmad, and Ali Ramschie. "Sistem Monitoring Dan Kendali Kerja Air Conditioning Berbasis Mikrokontroler ATmega 8535”, Jurnal Ristek Vol.2, No.1, Juni 2013.

[3] Mitar Simic, "Design and Development of Air Temperature and Relative Humidity Monitoring System with AVR Processor base Web Server", Electrical and 
Power Engineering (EPE), International Conference and Expocition on, 2014.

[4] A. Ramschie, J. Makal and V. P. Manado, "Modeling of Energy-Saving Mode Systems on Air Conditioning Equipment," 2018 International Conference on Applied Science and Technology (iCAST), Manado, Indonesia, 2018, pp. 492-497.

[5] Peraturan Mentri Energi dan Sumber Daya Mineral RI. No. 13 2012, tentang penghematan pemakaian tenaga listrik

[6] Alan G. Smith, "Introduction To Arduino", Alan G. Smith, 2011.

[7] Allegro mikrosistem.inc. Datasheet ACS712.

[8] Husnawati, Rossi Passarella, Sutarno dan Rendyansyah, "Perancangan dan Simulasi Energi Meter Digital Satu Phasa Menggunakan Sensor Arus ACS712", JNTETI Vol. 2. No. 4, November 2013. , 16x2 LCD Dataseheet. (http://www.enginerrsgarage.com $>16 \times 2-\mathrm{lcd}$ ) Searchword=lcd 16x2 diakses 8 juni 2018)

[9] Ali A. S. Ramschie, Johan F. Makal, and Veny V. Ponggawa. "Sistem Pendeteksi dan Penginformasi Kekotoran Penyaring Udara Pada Peralatan Air Conditioning Guna Penghematan Listrik." Prosiding
Industrial Research Workshop and National Seminar. Vol. 8. No. 3. 2017.

[10] Ali A S Ramschie, Johan F Makal and Veny V Ponggawa, "Method of Freon Leak Detection and Dirty Air Filter in Air Conditioning for Electrical Savings", International Journal of Computer Applications 172(1):35-40, August 2017

[11] Chiou. C.B., Chu C.M. dan Lin, S.L. "The study of energisaving strategy for direct expansion air conditioning system", Energi and Buildings 40. 16601665,2008 .

[12] Widell. K.N. dan Eikevik. T. "Reducing power consumption in multi -compressor refrigeration sistems", International Journal of Refrigeration 33. 88-94,2009.

[13] Zhou, Y.P., Wu, J.Y., Wang, R.Z. \& Shiochi, S."Energi simulation in the variable refrigerant flow airconditioning sistem under cooling conditions" Energi and Buildings 39. 212-220, 2007.

[14] Ali A.S. Ramschie, Johan Makal, Veny Ponggawa, "Algorithms Air Conditioning Air Filter Detection System For Electric Energy Savings", International Journal of Computer Application (IJCA), Vol. 156 No. 8, 2016. 